\title{
TEXID \\ THE LUPUS ERYTHEMATOSUS CELL INCLUSION PHENOMENON
}

\author{
BY
}

\author{
S. HOLMAN
}

From the Department of Pathology, Postgraduate Medical School of London

(RECEIVED FOR PUBLICATION JANUARY 11, 1951)

In 1948 Hargraves and his associates at the Mayo Clinic described two new entities in marrow biopsy material, the "tart " cell and the "lupus erythematosus" (L.E.) cell. Since then the morphology and the mechanism of production of these "cells" have been intensively studied in the United States. It is the purpose of this communication to report the finding of L.E. cells in the bone marrow films of four cases of acute disseminated lupus erythematosus.

\section{Morphology}

Lupus erythematosus cells are cells containing a homogeneous mass of apparently phagocytosed material which stains purple with Romanowsky dyes. "Tart" cells are similar cells in which the inclusion body is not structureless but retains a recognizable chromatin pattern.

Usually, but not always, it is possible to recognize the type of host cell. Most of them are neutrophil polymorphonuclears or neutrophil band forms (Figs. 1, 4, and 6); very rarely eosinophils and monocytes are affected (Fig. 2). Myelocytes, promyelocytes, myeloblasts, erythroblasts, plasma cells, and lymphocytes have not been observed to contain these bodies. The affected cells are often found in clumps of three or four; occasionally larger clumps of 10 to 20 cells are seen (Fig. 3). These clumps are often associated with free, extracellular purple-staining masses morphologically and tinctorially identical with the inclusion bodies. Quite commonly and characteristically two or more cells are seen sharing one " body" (Fig. 4), and less commonly two "bodies" are found in one cell (Fig. 5).

\section{Methods for the Demonstration of Lupus Erythematosus Cells}

Lupus erythematosus cells cannot be found in films made at the time the marrow is aspirated. This has been emphasized by Dameshek and Bloom (1950), Berman, Axelrod, Goodman, and McClaughry (1950), Hargraves (1949), and Haserick and Bortz (1949), but is still insufficiently appreciated. This has also been the case in all four of the writer's patients. Lupus erythematosus cells were found in moderate numbers in citrated marrow preparations, prepared as described below, but careful observations on the corresponding direct marrow films failed to show even one L.E. cell. It is imperative, therefore, that some anticoagulant be used. The nature of the anticoagulant seems to be of small importance. Berman et al. (1950) and Haserick (1950b) used heparin $(0.1 \mathrm{mg} . / \mathrm{ml}$. of fluid) ; Heller and Paul's oxalate mixture as recommended by Wintrobe (1946) is also suitable. 


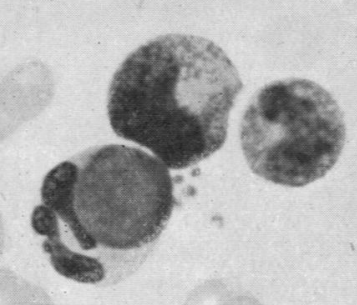

FIG. 1.-Neutrophil containing inclusion body. Citrated marrow film $\times 800$.

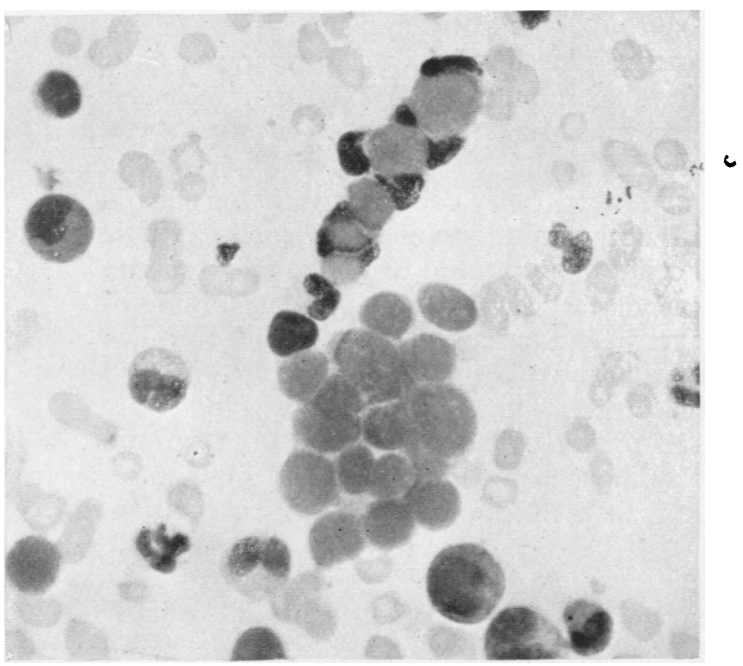

FIG. 3.-Clump of free masses and L.E. cells. Citrated marrow film $\times 490$.

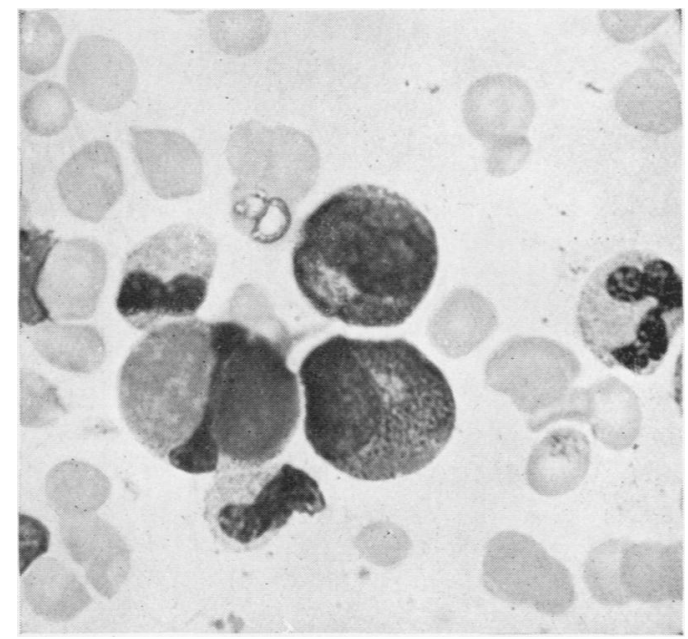

Fig. 5.-Two inclusion bodies in one cell. Citrated marrow film $\times 800$.

Fig. 2.-Monocyte containing inclusion body. Citrated marrow film $\times 800$.

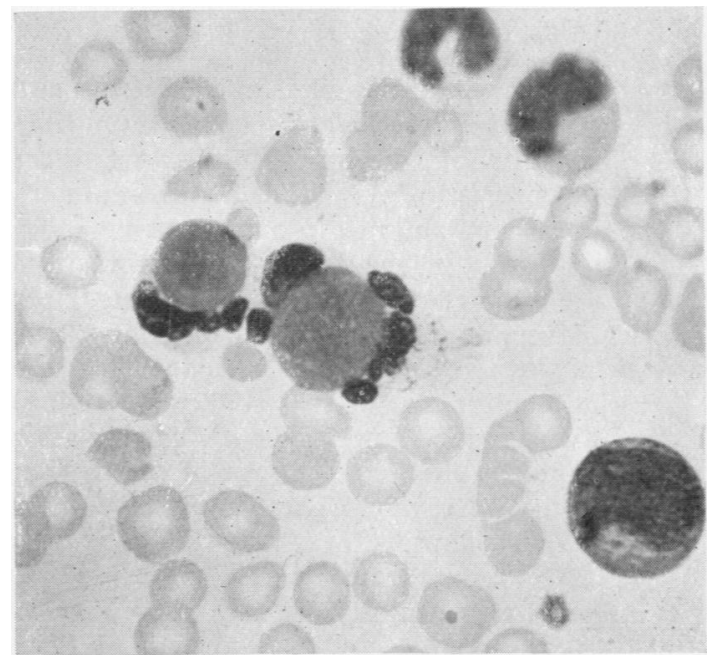

FIG. 4.-Two neutrophils surrounding one inclusion body. Citrated marrow film $\times 800$.

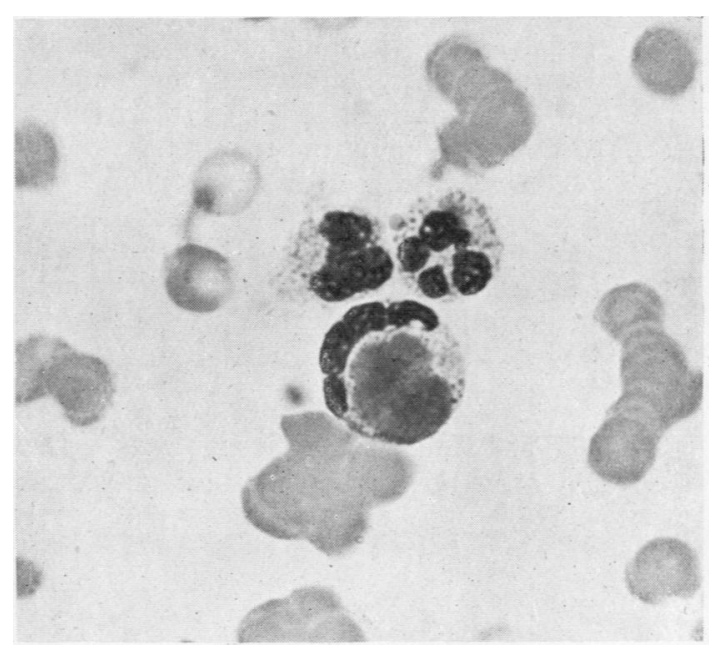

Fig. 6.-L.E. cell in peripheral blood. "Buffy coat" film from oxalated blood $\times 800$. 
Sporadic accounts of finding L.E. cells in the peripheral blood have been published (Sundberg and Lick, 1949 ; Hargraves, 1949 ; and Moffat, Barnes, and Weiss, 1950). They are said, however, to be found in too small numbers to assist in the diagnosis of acute disseminated lupus erythematosus. Nevertheless, in all four of the cases which I investigated the L.E. cells were demonstrated in appreciable numbers in the peripheral blood (Fig. 6). These preparations have proved quite as satisfactory diagnostically as the marrow preparations and have also been very useful for serial studies in attempting to assess alterations in the L.E.-producing factor in patients under treatment with A.C.T.H. This method obviates the necessity for doing repeated marrow punctures on sick patients.

\section{Recommended Techniques}

Bone Marrow.-The marrow puncture is done in the usual way. A small amount $(0.2-0.3 \mathrm{ml}$.) of marrow fluid is withdrawn, placed in a small $7 \times 30 \mathrm{~mm}$. tube containing two drops of $3 \%$ sodium citrate and gently mixed with the anticoagulant. The suspension of marrow is removed with a Pasteur pipette, placed without further delay in a Wintrobe haematocrit tube, and centrifuged for five minutes at 2,000 r.p.m. Longer centrifuging or higher speeds are unnecessary and may pack the cells too firmly. After centrifuging, the marrow separates into four layers. At the top is a fatty layer, below this a layer of plasma, below this the nucleated cell layer (buffy coat or myeloid-erythroid layer) containing the nucleated marrow cells of both granulopoietic and erythropoietic series, and at the bottom the non-nucleated red cells. The fat and upper layer of plasma are withdrawn by means of a Pasteur pipette and discarded, leaving behind a volume of plasma equal in volume to the nucleated cell layer. The remaining plasma and as much as possible of the nucleated cell layer is then withdrawn by a Pasteur pipette as well as a millimetre or two of the underlying red cell layer. The contents of the pipette are then emptied into a waxed watch-glass and well mixed by alternately drawing up and expelling the fluid. Drops of the fluid are finally placed on clean slides and films made in the usual way. These are allowed to dry in air, then fixed and stained as for ordinary marrow films.

Sodium citrate seems to be a preferable anticoagulant to heparin or mixed oxalates, because the solution is easy to prepare, and it is stable and reliable. In addition, staining is not impaired and the morphology of the marrow cells is not affected.

Peripheral Blood.-Blood is taken in suitable quantity into Heller and Paul's oxalate mixture (six parts ammonium oxalate, four parts potassium oxalate : $2 \mathrm{mg}$. of the mixed salts per ml. of blood), gently mixed, placed in a Wintrobe tube, and centrifuged for 15 minutes at 2,000-3,000 r.p.m. Centrifuging whole blood for a shorter time is, in general, insufficient to spin down the leucocytes satisfactorily. Most of the plasma is discarded, the "buffy coat" and upper millimetre of red cells are withdrawn, mixed, spread, and stained as for the marrow preparations.

Oxalate is preferred to citrate as the anticoagulant for peripheral blood solely because it is the best to use for other routine studies, which can therefore be carried out on the same venous sample. The technique must, however, be carried out shortly after withdrawing the blood or the leucocytes will show degenerative "oxalate" changes.

Hargraves (1949) has described a special container for centrifuging blood. This seems an unnecessary refinement, as the haematocrit tube has proved quite satisfactory.

\section{Discussion}

The Role of Anticoagulants.-It is interesting to speculate why L.E. cells can only be found in blood or marrow treated with anticoagulants and never in 
fresh films. As three such widely different chemical substances as heparin, sodium citrate, and potassium and ammonium oxalate mixture can be used, it is extremely unlikely that it is a direct chemical action on the cells. Furthermore, by using defibrinated blood (i.e., without any added anticoagulant) L.E. cells have been demonstrated in one case of the present series in which the method was tried. This method is not, however, recommended, as many leucocytes are necessarily lost in the process of defibrination. Lee, Michael, and Vural (1950) have also demonstrated L.E. cells in clotted blood. It seems, therefore, that the role of anticoagulant is to provide the time necessary for the plasma factor to act on the leucocytes. Failure to find L.E. cells in active cases of acute disseminated lupus erythematosus is probably due to not having used an anticoagulant (Stich, 1950).

The Plasma Factor.-It has been repeatedly shown (Haserick, 1950a ; Haserick, 1950b ; Moffat et al., 1950 ; Berman et al., 1950 ; Hargraves, 1949 ; and Haserick and Bortz, 1949) that the factor producing the alterations in the leucocytes is present in the plasma of patients with acute disseminated lupus erythematosus and not in the leucocytes themselves. Patient's plasma when incubated with normal human leucocytes, normal human marrow, or even animal marrow will produce typical L.E. cells. Haserick (1950a), by adding L.E. plasma to marrow and making films at 60 -second intervals, demonstrated that the leucocytes clumped five or six minutes after mixing and L.E. cells appeared after 12 to 13 minutes. The plasma factor is said to maintain its potency for a long period if kept below $-20^{\circ} \mathrm{C}$. Berman et al. (1950) have shown that the L.E. factor is present in the gammaglobulin plasma fraction.

Auxiliary Tests.-Various auxiliary methods have been used for demonstrating. the plasma L.E. factor. Haserick (1950a, b), Haserick and Bortz (1949), Berman et al. (1950), and Hargraves (1949) have used L.E. plasma mixed with bone marrow from patients with various diseases, and Haserick (1950b) and Berman et al. (1950) used L.E. plasma mixed with animal marrow (dog, rat, rabbit, guinea-pig). These methods all depend on the same phenomenon, that is the production of L.E. cells from leucocytes of varying sources by the action of the plasma of patients suffering from acute disseminated lupus erythematosus Berman et al. (1950) have shown that marrows of patients with miscellaneous disorders may vary markedly in their ability to produce L.E. cells when mixed with a potent plasma. This suggests that these auxiliary methods have no advantages over the simpler methods of examining the marrow and peripheral blood of the patient himself, and in fact may be inferior to them.

Specificity of the L.E. Cell Phenomenon.-Lupus erythematosus cells are found very frequently in acute disseminated lupus erythematosus (Montgomery and McCreight, 1949 ; Haserick, 1950 ; Hargraves, Richmond, and Morton, 1948 ; Hargraves, 1949 ; and Berman et al., 1950). The cells are found more frequently with increasing activity of the disease and are less frequent or even absent in spontaneous or induced remissions. They have been seen in isolated cases of multiple myelomatosis (Hargraves, quoted by Berman et al., 1950), in leukaemia (Vonder Heide, quoted by Berman et al., 1950) in pernicious anaemia in relapse, in dermatitis herpetiformis, in chronic discoid lupus, in chronic and subacute disseminated lupus erythematosus, and in "probable collagen disease, undetermined type" (Berman et al., 1950). Nevertheless, close investigation has in general failed to reveal L.E. 
cells in the so-called "collagen diseases," rheumatic fever, rheumatoid arthritis, scleroderma, dermatomyositis, periarteritis nodosa, subacute and chronic disseminated lupus erythematosus, and varying conditions like hepatic cirrhosis and unspecified leucopenias and hyperglobulinaemias (Haserick, 1950a, and Montgomery and McCreight, 1949). I have studied about 30 marrow preparations from patients suffering from a variety of diseases ; in no case were L.E. cells found. However, it should be emphasized that the free unphagocytosed, purple-staining masses which are so frequent in disseminated lupus erythematosus are far less diagnostic than L.E. cells and may even be found in normal marrows.

Histogenesis.-The inclusion bodies in the L.E. cells and the purple-staining free masses are nuclear in origin. They stain with Feulgen's reagent and with methyl green and show a strong absorption at 2537 angstroms $(253.7 \mathrm{~m} \mu)$, all of which indicate that they contain desoxyribose nucleic acid (Gueft, 1950). Morphological studies confirm this. Degeneration of nuclei can be seen in suitable marrow material. The affected nuclei become smudged and homogeneous and stain a purple colour, producing the free masses. The masses are then ingested by normal-looking leucocytes, thus producing the typical L.E. cells.

Berman et al. (1950), Klemperer, Gueft, Lee, Leuchtenberger, and Pollister (1950) and Klemperer, Gueft, and Lee (1949) feel that the L.E. cell is the counterpart of the haematoxylin-staining bodies found in various organs in disseminated lupus erythematosus. Nevertheless, the significance of the L.E. phenomenon and its relationship to the pathogenesis of disseminated lupus erythematosus must, for the moment, remain speculative. It has not even been established that the nuclear degeneration and production of L.E. cells occur in vivo.

\section{Summary}

The finding is reported of lupus erythematosus cells in the bone marrow and peripheral blood of four patients with acute disseminated lupus erythematosus.

The techniques which may be used in searching for these cells are discussed. The cells cannot be found in absolutely fresh preparations. An anticoagulant must be used and a pause of at least 10 to 15 minutes is necessary ; any anticoagulant (heparin, oxalate, or citrate) may be used.

The factor producing these phenomena resides in the plasma of the patients and not in their leucocytes.

Lupus erythematosus cells are very commonly found in acute disseminated lupus erythematosus, but only very exceptionally in other diseases.

My thanks are due to Dr. J. V. Dacie for his advice and encouragement, and to Mr. E. V. Willmot, F.R.P.S., for the photomicrographs.

\section{REFERENCES}

Berman, L., Axelrod, A. R., Goodman, H. L., and McClaughry, R. I. (1950). Amer. J. clin. Path., $20,403$.

Dameshek, W., and Bloom, M. L. (1950). B'ood, 5, 101.

Gueft, B. (1950). Arch. Derm. Syph., Chicago, 61, 892.

Hargraves, M. M. (1949). Proc. Mayo Clin., 24, 234.

Richmond, H., and Morton, R. (1948). Ibid.. 23, 25. 
Haserick, J. R. (1950a). Arch. Derm. Syph., Chicago, 61, 889.

(1950b). Amer. J. Path., 26, 704.

and Bortz, D. W. (1949). J. invest. Derm., 13, 47.

Klemperer, P., Gueft, B., and Lee, S. (1949). J. Mt Sinai Hosp., 16, 61.

- Leuchtenberger, C., and Pollister, A. W. (1950). Arch. Path., 49, 503.

Lee, S. L., Michael, S. R., and Vural, I. L. (1950). Bull. N.Y. Acad. Med., $26,266$.

Moffatt, T. W., Barnes, S. S., and Weiss, R. S. (1950). J. invest. Derm., 14, 153.

Montgomery, H., and McCreight, W. G. (1949). Arch. Derm. Syph., Chicago., 60, 356.

Stich. M. H.(1950). N.Y. St.J.Med., 50, 433.

Sundterg, R. D., and Lick, N. B. (1949). J. invest. Derm., 12, 83.

Wintrobe, M. M. (1946). Clinical Hematology, 2nd ed., London. 